\title{
ВПРОВАДЖЕННЯ ПАРТИСИПАТИВНОГО БЮДЖЕТУ
}

\section{Рецензент - доктор економічних наук В. В. Писаренко}

Стаття присвячена проблемам запровадження партисипативного бюджету, розробленому $i$ затвердженому за участі громадськості, фінансовому плану спільного управління, здійснюваного громадянами та місцевими органами влади. Сформовано визначення, окреслені учасники та иільові групи. Приведений зарубіжний досвід впровадження партисипативного бюджетування. Сформовано висновки щчодо формування високого рівня інтелектуальної обтрунтованості рішень за рахунок широкої участі мас у проиесі їх прийняття.

Ключові слова: партисипативний бюджет, громадськість, бюджет участі, партисипаторне суспільство, органи публічної влади, громадський бюджет.

Постановка проблеми. Партисипативне або учасницьке бюджетування як інструмент прямої демократії, за допомогою якого громадяни беруть участь у прийнятті рішень щодо розподілу бюджетних коштів, було вперше успішно втілене у бразильському м. Порту-Алегрі чверть століття тому. Сьогодні його використовують у півтори тисячі населених пунктів на всіх континентах, а сам термін входить до словників економістів усього світу та до переліку рекомендацій ООН щодо ведення міських бюджетів.

Партисипативний бюджет (Participatory Budget) це місцевий бюджет, розроблений і затверджений за участю громадськості, це фінансовий план спільного управління, здійснюваного громадянами та місцевими органами влади.

Найважливішою умовою демократичної участі суспільства $є$ соціальна рівність: принцип участі повинен ставитися і до недержавних суспільних інститутів, де люди прямо висловлюють свою волю. Свобода, рівне право на саморозвиток можуть бути досягнуті тільки в партисипаторному суспільстві, яке удосконалює почуття політичної ефективності та сприяє прояву турботи про колективні вимоги. У такому суспільстві громадяни добре проінформовані, зацікавлені у своїй високій активності у суспільному житті. Державне управління повинне допускати участь громадян не тільки у всенародних виборах влади, референдумах, зборах, але й безпосередньо в процесі прийняття рішень, а також у контролі над їх виконанням.

Партисипативний бюджет надає жителям міста можливість зробити свій внесок у розгляд та прийняття фінансових рішень щодо пріоритетних питань.

Такий підхід забезпечує максимальне врахування інтересів народу під час прийняття рішень, збільшує його активність у суспільному та державному житті, легітимізує владу в очах народу, виключає його відчуження від публічного управління.

Аналіз останніх досліджень і публікацій, у яких започатковано розв'язання проблеми. Зарубіжні та вітчизняні науковці, такі як Джефф Xay, S. M. Shapiguzov, А. К. Синягин, О. В. Дурандіна, I. В. Разорвін, О. В. Матвеєва розглядали питання партисипативних бюджетів як елемент в системі муніципального управління.

Рівного права на свободу та саморозвиток можна досягти лише в «учасницькому суспільстві» [1], яке виховує почуття політичної дієвості, навчає цікавості до спільних проблем та допомагає становленню обізнаного громадянства, здатного проявляти постійну зацікавленість у процесі урядування.

Участь громадян, на думку Дж. Ф. Ціммермана, має бути постійною й розпочинатися на стадії планування нової програми (чи проекту), і тривати після іiї запровадження, щоб забезпечити ефективність даної програми (чи проекту), «...всі громадяни повинні якомога більшою мірою мати рівні можливості для участі, слід забезпечити їм змогу висловитися, надати їм повну інформацію, доступ до засобів масової інформації тощо» [2].

Мета дослідження - впровадження партисипативних бюджетів.

Завдання дослідження - доведення до суспільства можливостей реальної участі у формуванні місцевих бюджетів.

Результати дослідження. Двадцятипятирічний термін існування України, як незалежної держави, приводить до розуміння, що на зміну революції має неодмінно прийти еволюційний розвиток і самовдосконалення. Потрібно братися 


\section{ЕКОНОМІКА}

за дедалі складніші завдання, освоювати все ефективніший інструментарій та вчитися у найкращих, щоб самим досягти успіху. Особливо, якщо альтернатива - залежність і приниження. Партисипативний бюджет або ж простіше - громадський бюджет - бюджет участі - один із елементів успішних західних демократій. Важливо те, що там це не прерогатива депутатів, юристів та економістів, а те, що в цьому можна взяти участь всім мешканцям міста, не маючи відповідної підготовки і отримати задоволення та користь. Що ж таке бюджет участі, i чи приживеться він в Україні?

Згідно із законодавством, рішення про прийняття місцевого бюджету - прерогатива міської ради, однак він може і повинен брати до уваги рекомендації, що надходять від громадян.

Те, що називається партисипативным бюджетом, у кожному місті виглядає по-своєму.

Тому необхідно дати мінімальне визначення, яке дало б змогу мешканцям різних європейських країн розуміти один одного. Будемо розуміти під словами «партисипативний бюджет» будь-який експеримент 3 участю громадян, що відповідає наступним умовам:

- обсяги наявних фінансових ресурсів і параметри бюджету повинні бути предметом дискуciï. Будь-яка схема участі побічно відбивається на ситуації у сфері фінансів, водночас бюджетування $з$ участю громадськості має справу виключно $з$ обмеженими ресурсами;

- партисипативне бюджетування зачіпає не тільки рівень, скажімо, мікрорайону, у цей процес повинен також бути включений рівень міста (або району) або, наприклад, район 3 обраною радою і визначеними повноваженнями щодо місцевої адміністрації, як це має місце у великих містах Європи. Наявність муніципального фонду в межах мікрорайону або ради мікрорайону як такого не $є$ свідченням бюджетування з участю громадськості;

- процес повинен мати постійний характер: одне єдине засідання або один референдум 3 фінансових питань не $є$ партисипативним бюджетуванням;

- громадськість повинна брати участь в обговоренні бюджету в спеціально створених для цього рамках засідання міської ради, відкритих для присутності громадян у момент обговорення міського бюджету - це не є процесом прийняття партисипативного бюджету;

- для забезпечення певного рівня участі громадян у розробці і прийнятті бюджету недостатньо зробити роботу міської фінансової комісії доступною для присутності жителів;
- у рамках процесу залучення громадян до розробки бюджету необхідне забезпечення зворотнього зв'язку, що стосується отриманих результатів. Якщо має місце публічна дискусія 3 питань складання бюджету без інформування громадян про результати цієї дискусії, не можна говорити про участь жителів у бюджетуванні.

Концепція та процедура розробки партисипативного бюджету, як це часто буває 3 нестандартними політичними процесами, являють собою не тільки новий шлях до знаходження рішень складних питань, але й виклик для різних груп діючих осіб, залучених до нової форми взаємодії, яка заснована на дещо зміненому уявленні про те, що таке «політика» на локальному рівні.

Політичні процеси не повинні залишатися прерогативою мерів, членів місцевих рад та місцевої адміністрації, громадяни повинні мати змогу заявляти про свої ідеї і погляди щодо прийняття будь-яких рішень. 3 іншого боку, громадяни повинні бути готові взяти на себе частину роботи i певну частку відповідальності. Цей процес часто в психологічному i практичному плані отримує підтримку завдяки нинішньому процесу модернізації систем місцевого управління. Крім цього, безперервно збільшується дефіцит фінансових ресурсів. У зв'язку з цим росте і усвідомлення необхідності спільного вирішення проблем. Як уже згадувалося, в процесі прийняття політичних рішень i, особливо, в процесі участі громадян у розробці та затвердженні бюджетів можна виділити чотири різні групи зацікавлених осіб: громадяни, члени місцевої адміністрації, політики і представники бізнесу.

Що спонукає ці групи брати участь у такого роду процесі? До яких загроз ми повинні бути готові, і які вигоди можна очікувати від цього процесу?

Для місцевої адміністрації можна виявити цілу низку мотивів для участі в процесі партисипативного бюджетування. Одним із моментів $є$ зниження рівня визнання легітимності рішень перед обличчям зменшуваних бюджетів; деякі адміністрації відкрито або в завуальованій формі кажуть, що партисипативне бюджетування спрямоване на те, щоб покласти на громадян більший обсяг відповідальності за прийняття рішень на локальному рівні; рішення або пріоритети, що отримали підтримку самих громадян, сприймаються як більш легітимні, ніж у випадках, коли вони приймаються місцевою радою одноосібно.

Наступний фактор мотивації - прагнення удосконалити на муніципальному рівні процеси, що відносяться до організації діалогу між адміністрацією та громадянами. Використовують таку 


\section{ЕКОНОМІКА}

модель у прийнятті політичних рішень, прагнуть розвивати процес прийняття рішень, в основному в довгостроковій перспективі, в напрямі відкритого діалогу між громадянами та адміністрацією. Однак такий сервіс орієнтованого подання в якості стимулу для участі в процесі спільного бюджетування зустрічається досить рідко, принаймні за межами рівня мікрорайонів.

Перш за все, громадяни беруть участь у процесі, поскільки хочуть вчасно отримувати інформацію про політичні та фінансові рішення, що приймаються на рівні їх муніципального утворення. Крім цього, громадяни хочуть мати можливість озвучувати свої власні ідеї та пріоритети. Громадяни також прагнуть до участі в цьому процесі, щоб зробити свій внесок у забезпечення вищої якості життя в їх власному муніципальному утворенні. Об'єднання може побоюватися того, що участь окремих громадян, або тих, які керуються власним інтересом чи призначених за квотою, здатні підірвати основи їх організації або її потенціал для проведення переговорів.

Для місцевих політичних діячів ситуація знову ж таки представляється інакше. Члени місцевих парламентів і місцевих рад часто сприймають розширення участі громадян як зайве, поскільки побоюються того, що це становить загрозу для їх ключових повноважень. У деяких випадках мери одноосібно приймали рішення про розробку партисипативного бюджету, тим самим відсуваючи на другий план членів міської ради.

Стимулом для взаємодії може бути можливість знайомитися з ідеями громадян і використовувати їх у рамках прийняття адміністративних рішень, підвищуючи тим самим рівень легітимності останніх. Корисно також дізнаватися від першоджерел, із чого складаються пріоритети громадян. Таким чином можна забезпечити більшу підтримку політичних рішень.

Якщо усі партнери довіряють один одному i законно взаємодіють, то такий новий вид співпраці на муніципальному рівні сприяє прийняттю нових креативних рішень з урахуванням бюджетних дефіцитів. Важливо, щоб місцева рада i мер активно брали участь у процесі розробки партисипативного бюджету. Форми співробітництва і проведення спільних обговорень можуть узгоджуватися між членами ради й за участі громадян.

Представники бізнесу поки що не є активними учасниками процесів розробки і затвердження партисипативних бюджетів. Ця ситуація значно відрізняється від прийнятого ООН «Порядку денного на XXI століття», де, як правило, представлений і бізнес. Найчастіше бізнес незацікавлений в участі громадськості у розробці бюджетів, адже має власні канали спілкування 3 місцевою адміністрацією. Він побоюється заперечень 3 боку активістів муніципальних об'єднань у процесі прийняття бюджету. Тим не менш, деколи корисно зібрати всі суб'єкти разом, тому деякі об'єднання на муніципальному рівні воліють бачити серед учасників процесу розробки бюджету i представників бізнесу, а не залишати їх поза рамками цього процесу: це, як мінімум, дає можливість залучити їх у публічну дискусію і заперечувати певні рішення у присутності своїх апонентів. У деяких випадках, якщо партисипативний бюджет $є$ наслідком реалізації схем приватно державного партнерства, бізнес бере участь в якості одного з донорів або навіть основного донора. У тих випадках, коли участь громадськості в бюджетуванні реально впливає на процес прийняття рішень, бізнес може бути зацікавлений в участі. В інших випадках участь бізнесу в розробці партисипативного бюджету спільно 3 громадянами може бути результатом політичного рішення місцевої адміністрації.

Висновок. В основі наведених твердженьпереконання про здатність громадян не лише брати участь у виборах, референдумах, плебісцитах, а й безпосередньо у політичному процесі, підготовці, прийнятті та впровадженні владних рішень. Партисипаторна теорія демократії виходить $з$ того, що людина - істота раціональна, здатна свідомо приймати розумні рішення. Прихильники демократії участі вважають, що ірраціональність і пасивність людей у політичній сфері - це результат їх недостатньої освіти й відсутності рівних можливостей для участі в політиці. Тому суспільству належить створити всі умови для активної політичної соціалізації кожного індивіда.

Широке залучення освічених громадян до політичного процесу, децентралізація і контроль за прийняттям найважливіших рішень має поліпшити перспективу досягнення дійсної свободи i рівності, розширити інтелектуальний потенціал для прийняття рішень, підвищити стабільність політичної системи, ефективність управління, контроль за посадовими особами.

В Україні триває конкретний проект польськоукраїнської фундації співпраці PAUCI, у межах якого українські міста - Черкаси, Чернігів та Полтава, - дотримуючись усіх вимог цього процесу, вже за кілька тижнів завершать створення власних повноцінних бюджетів участі. 


\section{EKOHOMIKA}

\section{БІБЛІОГРАФІЯ}

1. Гелд Девід Моделі демократії : антологія / Девід Гелд ; [упорядк. О. Проценко]. - К. : Смолоскип, 2005. - С. 173.

2. Ціммерман Джозеф Ф. Учасницька демократія: відродження популізму : антологія / Джозеф Ф. Ціммерман ; [упорядк. О. Проценко]. - К. : Смолоскип, 2005. - С. 254. 